Review Article

\title{
Therapeutic Potential of Isoflavones with an Emphasis on Daidzein
}

\author{
Mohammed M. Alshehri (DD, ${ }^{1}$ Javad Sharifi-Rad $\left(D,{ }^{2}\right.$ Jesús Herrera-Bravo ${ }^{D},{ }^{3,4}$ Evelyn L. Jara, ${ }^{3}$ \\ Luis A. Salazar $\mathbb{D}^{4}{ }^{4}$ Dorota Kregiel $\mathbb{D},{ }^{5}$ Yadav Uprety, ${ }^{6}$ Muhammad Akram, ${ }^{7}$ \\ Mehwish Iqbal $\left(D,{ }^{8}\right.$ Miquel Martorell $\left(D,{ }^{9}\right.$ Margalida Torrens-Mas, ${ }^{10}$ \\ Daniel Gabriel Pons $\mathbb{D}^{11}$, Sevgi Durna Daștan, ${ }^{12,13}$ Natália Cruz-Martins $\mathbb{D}^{14,15,16}$ \\ Fethi Ahmet Ozdemir, ${ }^{17}$ Manoj Kumar $\mathbb{D}^{18}$ and William C. Cho $\mathbb{D}^{19}$
}

${ }^{1}$ Pharmaceutical Care Department, Ministry of National Guard-Health Affairs, Riyadh, Saudi Arabia

${ }^{2}$ Phytochemistry Research Center, Shahid Beheshti University of Medical Sciences, Tehran, Iran

${ }^{3}$ Departamento de Ciencias Básicas, Facultad de Ciencias, Universidad Santo Tomas, Chile

${ }^{4}$ Center of Molecular Biology and Pharmacogenetics, Scientific and Technological Bioresource Nucleus, Universidad de La Frontera, Temuco 4811230, Chile

${ }^{5}$ Department of Environmental Biotechnology, Lodz University of Technology, Wolczanska 171/173, 90-924 Lodz, Poland

${ }^{6}$ Amrit Campus, Tribhuvan University, Kathmandu, Nepal

${ }^{7}$ Department of Eastern Medicine and Surgery, Directorate of Medical Sciences, GC University Faisalabad, Pakistan

${ }^{8}$ Institute of Health Management, Dow University of Health Sciences, Karachi, Pakistan

${ }^{9}$ Department of Nutrition and Dietetics, Faculty of Pharmacy and Centre for Healthy Living, University of Concepción, 4070386 Concepción, Chile

${ }^{10}$ Translational Research In Aging and Longevity (TRIAL Group), Health Research Institute of the Balearic Islands (IdISBA), 07122 Palma, Spain

${ }^{11}$ Grupo Multidisciplinar de Oncología Traslacional (GMOT), Institut Universitari d'Investigació en Ciències de la Salut (IUNICS), Universitat de les Illes Balears (UIB), Instituto de Investigación Sanitaria Illes Balears (IdISBa), 07122 Palma, Spain

${ }^{12}$ Department of Biology, Faculty of Science, Sivas Cumhuriyet University, 58140 Sivas, Turkey

${ }^{13}$ Beekeeping Development Application and Research Center, Sivas Cumhuriyet University, 58140 Sivas, Turkey

${ }^{14}$ Faculty of Medicine, University of Porto, Alameda Professor Hernâni Monteiro, 4200-319 Porto, Portugal

${ }^{15}$ Institute for Research and Innovation in Health (i3S), University of Porto, 4200-135 Porto, Portugal

${ }^{16}$ Institute of Research and Advanced Training in Health Sciences and Technologies (CESPU), Rua Central de Gandra, 1317, 4585116 Gandra, PRD, Portugal

${ }^{17}$ Department of Molecular Biology and Genetics, Faculty of Science and Art, Bingol University, Bingol 1200, Turkey

${ }^{18}$ Chemical and Biochemical Processing Division, ICAR-Central Institute for Research on Cotton Technology, Mumbai 400019, India

${ }^{19}$ Department of Clinical Oncology, Queen Elizabeth Hospital, Kowloon, Hong Kong

Correspondence should be addressed to Javad Sharifi-Rad; javad.sharifirad@gmail.com, Jesús Herrera-Bravo; jehebra2@gmail.com, Miquel Martorell; martorellpons@gmail.com, Natália Cruz-Martins; ncmartins@med.up.pt, and William C. Cho; chocs@ha.org.hk

Received 19 July 2021; Accepted 26 August 2021; Published 10 September 2021

Academic Editor: German Gil

Copyright (c) 2021 Mohammed M. Alshehri et al. This is an open access article distributed under the Creative Commons Attribution License, which permits unrestricted use, distribution, and reproduction in any medium, provided the original work is properly cited.

Daidzein is a phytoestrogen isoflavone found in soybeans and other legumes. The chemical composition of daidzein is analogous to mammalian estrogens, and it could be useful with a dual-directional purpose by substituting/hindering with 
estrogen and estrogen receptor (ER) complex. Hence, daidzein puts forth shielding effects against a great number of diseases, especially those associated with the control of estrogen, such as breast cancer, diabetes, osteoporosis, and cardiovascular disease. However, daidzein also has other ER-independent biological activities, such as oxidative damage reduction acting as an antioxidant, immune regulator as an anti-inflammatory agent, and apoptosis regulation, directly linked to its potential anticancer effects. In this sense, the present review is aimed at providing a deepen analysis of daidzein pharmacodynamics and its implications in human health, from its best-known effects alleviating postmenopausal symptoms to its potential anticancer and antiaging properties.

\section{Introduction}

Nutraceuticals contain selective combinations of specific plant-derived bioactive components with renowned medicinal, disease-preventing, and/or health-enhancing properties. Such compounds include polyphenols, carotenoids, flavonoids, isoflavonoids, terpenoids, glucosinolates, phytoestrogens, and phytosterols. Studies on these phytochemicals have also shown positive pharmacological activities in human health [1].

Regarding phytochemical-rich plant sources, and to what concerns to isoflavonoid sources, soybeans and other leguminous plants are the main sources of active isoflavones genistein and daidzein [2]. Daidzein [7-hydroxy-3-(4hydroxyphenyl)-4H-1-benzopyran-4-one] (Figure 1) is a naturally occurring phytoestrogen fitting into the category of nonsteroidal estrogens [3], with numerous pharmacological activities, such as antihemolytic, antioxidant, and antiinflammatory activities $[4,5]$. Daidzein can be found in soy-derived food products such as soy-based infant formulas, soy flour, textured soy protein, soy protein isolates, tofu, tempeh, and miso. In addition, soy flour is used for the fortification of other flours, including wheat, rice, and corn. The daidzein content of these products is quite variable, i.e., the daidzein amount is $22 \mathrm{mg}$ in a half cup of miso, $15 \mathrm{mg}$ in 3 ounces of tempeh, $8 \mathrm{mg}$ in 3 ounces of tofu, and $7 \mathrm{mg}$ in one cup of soy milk [6].

The chemical structure of daidzein is analogous to mammalian estrogens, making it a promising candidate for a dual purpose by substituting/hindering such hormones and their corresponding receptors. Hence, daidzein could be a therapeutic strategy for estrogen-dependent health conditions, such as breast [7] and prostate [8] cancer, diabetes, osteoporosis, and cardiovascular disease (CVD) [9]. However, daidzein also has other estrogen receptor- (ER-) independent biological activities, for instance, the ability to reduce oxidative damage, regulate the immune reaction [10], and induce apoptosis, directly linked to their anticancer effects [11]. Thus, such activities, along with minimum toxicity features, make daidzein a promissory compound for drug design. In this sense, the present review is aimed at providing an in-depth overview of daidzein's potential use to prevent or treat some burdening human health conditions. First, we focus on daidzein's pharmacodynamics and current limitations for its use. Then, we briefly describe some proposed mechanisms of action, and finally, we review its implications in human health showing the latest research in the field, namely, focusing on its ability to alleviate postmenopausal symptoms, and its potential anticancer and antiaging properties.

\section{Daidzein Pharmacodynamics}

Daidzein is predominantly found in soy and many unfermented foods not only in the form of daidzin, a glycoside conjugate $[12,13]$, but also as acetylglycoside and aglycone [14]. Daidzin is not directly absorbed in the gut and instead needs to be hydrolyzed into the aglycone form daidzein [15] by $\beta$-glucosidases in the small intestine [16]. The aglycone form is either absorbed or metabolized to different types of metabolites by human gut bacteria, including dihydrodaidzein [15], equol, and O-desmethylangolensin (O-DMA, a metabolite with no estrogenic activity) (Figure 2) [17]. This intestinal biotransformation is accomplished through several reactions, such as reduction, methylation and demethylation, hydroxylation, and C-ring cleavage [18]. The absorbed aglycone is metabolized mainly to glucuronidated derivatives and, to a lesser extent, into sulfated conjugates by phase I and II enzymes [19-21]. Then, these metabolites can be further metabolized in the liver or might be secreted into the bile and recycled [22]. Finally, both the unabsorbed daidzein and biliary derivatives that reach the colon undergo deconjugation by bacterial enzymes and are then reabsorbed or metabolized [18, 22-25].

Studies on daidzein absorption, bioavailability, distribution, and excretion are still limited [15, 26, 27], with data obtained so far revealing the appearance of a small peak in plasma around $1 \mathrm{~h}$ after ingestion, with daidzein being absorbed in the small intestine [28]. A larger peak appears after 5-8 h, from the conjugates recycling and colon absorption. Interestingly, daidzein can be found in plasma mostly in its conjugated form and a small proportion in the form of aglycone [29]. A clinical study showed that daidzein ingestion in the form of glucoside results in higher bioavailability than consuming the aglycone form [30], while a previous study showed contrary data [31]. These controversial results could be explained by differences in the type of glycosides or the influence of other isoflavones on their metabolism [32]. Regardless of these studies, it seems that daidzein reaches the maximum concentration in plasma approximately $7 \mathrm{~h}$ after ingestion [33], which appears to be directly linked to its complex absorption process. Finally, a study by Setchell et al. [33] suggested that almost all daidzein is rapidly absorbed and metabolized, as the excretion in feces and urine was minimal, although up to $30 \%$ of daidzein intake can be recovered in urine.

Regarding daidzein's biological activity, as well as of other isoflavones, it is highly dependent on their biotransformation, and huge differences have been stated in daidzein metabolism between humans, rats, and mice, which suggest that not all research studies regarding daidzein and its effects 


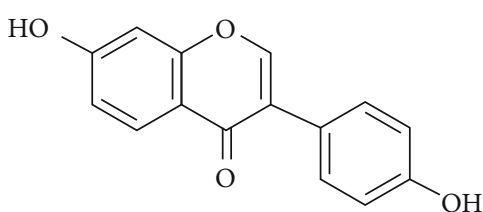

FIGURE 1: Chemical structure of daidzein.

can be extrapolated to humans. In humans, glucuronides are the major plasma phase II metabolites and the proportion of plasma daidzein and other aglycones (0.5-1.3\%) is significantly low compared to other animals [21].

Several factors, such as age, gender, or diet, have been described to influence the bioavailability of isoflavones in humans. For instance, the main source of isoflavones among the Asian population is fermented soy products, which contain isoflavones in the form of aglycones and can be directly absorbed. On the other hand, in the Western diet, the principal source is cooked soybeans, soy milk, and vegetable proteins, which contain the glucoside form [34]. Interestingly, an increased daidzein intake or its prolonged consumption appears not to change its bioavailability or pharmacokinetics (Setchell, Faughnan, Avades, Zimmer-Nechemias, Brown, Wolfe, Brashear, Desai, Oldfield, Botting and [3]).

Another important factor that determines daidzein bioavailability is the different food matrices used $[26,35]$. Cassidy et al. [36] showed that daidzein absorption is faster when consuming soy milk, with glucoside conjugates, than solid soy food, with a significant difference of $2 \mathrm{~h}$. Another study found that insoluble fiber, such as inulin, might increase the daidzein absorption $[37,38]$, partly due to bacterial growth stimulation [9]. However, there is a key aspect of daidzein metabolism that needs to be considered when studying its potential benefits. Plasma levels do not correlate well with the concentration that may effectively reach the different tissues. In fact, the quantification of isoflavones and their derivatives in human tissues is not usually determined and can vary in a large extent [24]. For instance, in humans, equol levels range between 22 and $36 \mathrm{nmol} / \mathrm{kg}$ in breast adipose tissue and $456-559 \mathrm{nmol} / \mathrm{kg}$ in glandular tissue [23, 39].

These complex daidzein pharmacokinetic features, along with its insolubility in water and oil, have blocked their use as a highly common compound in medicine or as a nutraceutical. Thus, several strategies have been developed to enhance daidzein's bioavailability, including emulsifying formulations or encapsulation with cyclodextrins [9]. For example, Peng et al. [40] designed fat-soluble derivatives by sulfonic acid esterification and stated that these are able to improve both daidzein cell uptake and its biological activities. Several techniques for modification of natural compounds are being developed and are discussed in other reviews $[41,42]$.

Equol $\left(4^{\prime}, 7\right.$-isoflavandiol $)$ is the daidzein metabolite that shows the strongest biological activity. Only a small percentage of the world population can metabolize daidzein to equol by gut bacteria [43]. The equol nonproducers, which have a prevalence between 80 and $90 \%$ in human subjects, convert a large part of daidzein into O-DMA [18]. Equol and $O$-DMA are likely produced by different bacterial taxa. $\mathrm{Lu}$ and Anderson [44] documented that only 30\% of their study population presented equol conjugates in urine following soy administration, and no differences were reported regarding the type of diet. Furthermore, a prolonged soy intake led to the ability to produce equol in a small fraction of equol nonproducer women. In this regard, some known factors that limit the ability to produce equol are ethnicity and dietary habits [18]. For instance, up to $50-70 \%$ of the Asian population are equol producers, compared to only $20-30 \%$ of Western individuals [45]. Brown et al. [46] suggested that the ability to produce equol is developed during the first years of life, and it appears to be related to the diet composition in the early years, as they observed that breastfed infants showed the lowest percentage of equol producers. Some other studies have tried to improve equol production by dietary habit modification. For example, Kruger et al. [47] analyzed the effects of a supplement of isoflavones with kiwifruit, expecting to see an improvement in equol production. Surprisingly, supplementation with kiwifruit had no effect on equol production and, in fact, attenuated the effects of isoflavone supplementation on reducing high-density lipoprotein (HDL) levels in postmenopausal women. Fructo-oligosaccharide supplementation also failed to increase equol production in postmenopausal Japanese women [48].

So far, most equol-producing bacterial strains belong to the family of Coriobacteriaceae, and they include Adlercreutzia equolifaciens, Asaccharobacter celatus, Enterorhabdus mucosicola, and Slackia isoflavoniconvertens and Slackia equolifaciens. Other equol-producing strains have also been identified, namely, Bifidobacterium, Lactobacillus, Lactococcus, Pediococcus, and Proteus species [18]. The involvement of gut microbiota in daidzein metabolism highlights the importance of analyzing how diet and, specifically, how soy products can affect the balance of such microorganisms and understand the triggers for individual differences [43]. For instance, a recent study showed that isoflavone administration did not change the copy number of Coriobacteriaceae species in feces regardless of diet [18]. Iino et al. [49] reported that daidzein intake increased with age, as also the ability to produce equol. Interestingly, both equol producers and nonproducers held equol-producing bacteria, although the relative abundance of 2 species, namely, $A$. celatus and S. isoflavoniconvertens, was significantly higher in equol producers.

\section{Daidzein Pharmacological Activities: Emphasis on Clinical Evidence}

Epidemiological data suggest that isoflavone consumption may have health benefits and lower the risk of some agerelated diseases, including osteoporosis, CVD, and several types of cancer, as well as reduce menopause-associated symptoms [18]. Table 1 resumes the different human studies reporting the effects of daidzein or isoflavones in several disorders. 


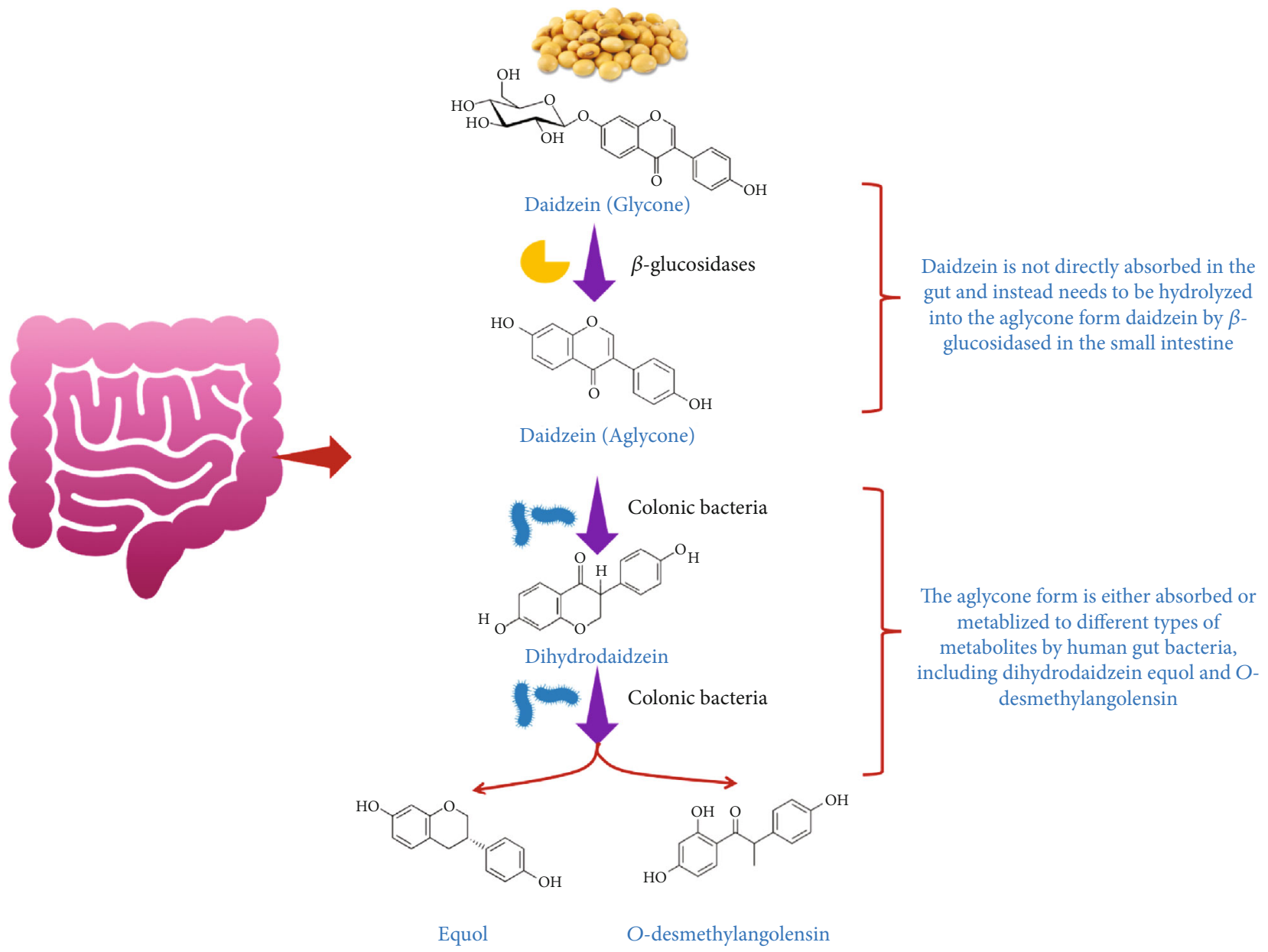

Figure 2: Biotransformation of daidzein in human gut.

In the Asian population, with a predominance of soy products in their diet, isoflavone intake can be up to $50 \mathrm{mg} /$ day, while in Western countries, it is less than $2 \mathrm{mg}$, although it may be higher in menopausal women [109]. As a phytoestrogen, daidzein may induce its effects through the interaction with ERs, as it possesses a strong similarity with $17-\beta$-estradiol (E2), the main female sex hormone. Two ER subtypes, namely, $\operatorname{ER} \alpha$ and $\operatorname{ER} \beta$, have been described with different tissue distribution and ligand-binding affinities. ER $\alpha$ is mainly found in breast and uterine tissues and has been associated with higher cell proliferation. On the other hand, ER $\beta$ is the predominant isoform in the brain, bones, and blood vessels and is related to cell differentiation. Thus, to assess the overall effects of daidzein or any other phytoestrogen, the $\mathrm{ER} \alpha / \mathrm{ER} \beta$ ratio needs to be considered, as the cell response may considerably differ from one tissue to another $[110,111]$.

Both daidzein and equol are $\operatorname{ER} \alpha$ and $\operatorname{ER} \beta$ agonists, with higher affinity for the latter, and can interfere with their signaling pathway. However, other ER-independent signaling mechanisms have been described, including protein kinase regulation, enzymatic inhibition, growth factor modulation, antioxidant activity, or epigenetic changes [111].
3.1. Daidzein and Allergies. Although estrogens are known to regulate the immune response, epidemiologic studies assessing the association between dietary isoflavones and allergic disorders are still limited. Miyake et al. [50] suggested that soy consumption and daidzein may reduce allergic rhinitis in Japanese women, although there was no dose-response effect. On the other hand, other products, such as tofu or fermented soybeans, showed no differences in allergic rhinitis prevalence. Nonetheless, it must be taken into account that soy is a strong food allergen, thus its consumption may be counterproductive when it comes to allergic disorders. Smith et al. [51] evaluated the soy isoflavone supplementation in poorly controlled asthmatic patients and found no differences in lung function between control patients and patients with isoflavone supplementation.

\subsection{Effects of Daidzein on Osteoporosis and Menopausal} Symptoms. Osteoporosis has a high incidence among menopausal women as estrogens regulate bone metabolism and ultimately prevent bone loss. Thus, the reduction in estrogens is associated with a higher risk of osteoporosis, and hormone replacement therapy has been proposed as a solution to reduce such risk [112]. In this regard, soy isoflavones have also been studied to prevent osteoporosis. Indeed, isoflavone supplementation for 4 and 6 months in 
TABle 1: Pharmacological activities of daidzein reported in human studies.

\begin{tabular}{|c|c|c|c|c|}
\hline $\begin{array}{l}\text { Pharmacological } \\
\text { activity }\end{array}$ & Study type & Dose/type of treatment & Results & References \\
\hline \multirow[t]{2}{*}{ Antiallergic } & $\begin{array}{l}\text { Cross- } \\
\text { sectional } \\
\text { study }\end{array}$ & Regular soy products consumption & $\begin{array}{l}\text { Possible reduction in allergic rhinitis } \\
\text { incidence }\end{array}$ & {$[50]$} \\
\hline & $\mathrm{RCT}$ & $100 \mathrm{mg}$ isoflavones/day, 24 weeks & No effects & {$[51]$} \\
\hline \multirow{6}{*}{ Antiosteoporotic } & $\mathrm{CT}$ & $\begin{array}{c}59.6 \mathrm{mg} \text { genistein }+15.6 \mathrm{mg} \text { daidzein/day, } 6 \\
\text { months }\end{array}$ & $\begin{array}{c}\text { Increase in bone mineral density in lumbar } \\
\text { spine and decrease bone resorption } \\
\text { biomarkers }\end{array}$ & {$[52]$} \\
\hline & $\mathrm{CT}$ & $70 \mathrm{mg}$ isoflavones/day, 12 weeks & Increase in bone formation markers & {$[53]$} \\
\hline & CT & $\begin{array}{l}60 \mathrm{mg} \text { genistein }+60 \mathrm{mg} \text { daidzein }+16.6 \mathrm{mg} \\
\text { glycitein, } 5 \text { days/week, } 2 \text { years }\end{array}$ & No direct effects on serum calcium levels & {$[54]$} \\
\hline & RCT & $105.23 \mathrm{mg}$ isoflavones/day, 50 days & Increase in calcium retention & {$[55]$} \\
\hline & CT & $136.6 \mathrm{mg}$ isoflavones, 5 days/week, 2 years & $\begin{array}{l}\text { Decrease in mineral bone density with low } \\
\text { calcium levels }\end{array}$ & {$[56]$} \\
\hline & SR & $\begin{array}{c}\text { Different isoflavone extracts, } 7 \text { weeks up to } 3 \\
\text { years }\end{array}$ & $\begin{array}{l}\text { Bone health improvement and blocked } \\
\text { mineral density loss }\end{array}$ & {$[57]$} \\
\hline \multirow{9}{*}{$\begin{array}{l}\text { Menopausal } \\
\text { symptoms } \\
\text { reduction }\end{array}$} & RCT & 10,20 , or $40 \mathrm{mg}$ equol/day, 8 weeks & $\begin{array}{l}\text { Reduced hot flash frequency and improved } \\
\text { muscle and joint pain }\end{array}$ & {$[58]$} \\
\hline & RCT & $10 \mathrm{mg}$ equol, 1 or 3 times/day, 12 weeks & Anxiety scores reduction & [59] \\
\hline & CT & $10 \mathrm{mg}$ equol/day, 12 weeks & $\begin{array}{l}\text { Reduced hot flash frequency and severity, } \\
\text { improved sweating and muscle stiffness }\end{array}$ & {$[60]$} \\
\hline & RCT & $135 \mathrm{mg}$ isoflavones/day, 1 week & Improved hot flashes, sweating and fatigue & {$[61]$} \\
\hline & $\mathrm{CT}$ & $100-200 \mathrm{mg}$ isoflavones/day, 12 weeks & Improved hot flash intensity & {$[62]$} \\
\hline & $\mathrm{CT}$ & $63 \mathrm{mg}$ daidzein/day, 6 months & Improved renal function & {$[63]$} \\
\hline & RCT & $150 \mathrm{mg}$ isoflavones/day, 16 weeks & No effects on menopausal symptoms & [64] \\
\hline & SR & Different isoflavones extracts, $3-12$ months & Possible reduction in hot flash frequency & {$[65]$} \\
\hline & SR & $\begin{array}{c}\text { Different isoflavones extracts, } 12 \text { weeks to } 4 \\
\text { years }\end{array}$ & $\begin{array}{c}\text { Reduced hot flash frequency, improved } \\
\text { vascular health, no effects on urogenital } \\
\text { symptoms }\end{array}$ & {$[66]$} \\
\hline \multirow{11}{*}{ Anticancer } & $\begin{array}{l}\text { Cohort } \\
\text { study }\end{array}$ & $\begin{array}{c}\text { Regular soy products consumption, } 23 \\
\text { months }\end{array}$ & $\begin{array}{l}\text { Reduced recurrence in tamoxifen-treated } \\
\text { breast cancer patients }\end{array}$ & {$[67]$} \\
\hline & $\begin{array}{l}\text { Cohort } \\
\text { study }\end{array}$ & Regular soy products consumption, 3.9 years & $\begin{array}{l}\text { Reduced mortality and recurrence of breast } \\
\text { cancer }\end{array}$ & [68] \\
\hline & $\begin{array}{l}\text { Meta- } \\
\text { analysis }\end{array}$ & Regular isoflavones consumption & Decreased risk of breast cancer & [69] \\
\hline & $\begin{array}{l}\text { Review with } \\
\text { meta- } \\
\text { analysis }\end{array}$ & Regular phytoestrogen consumption & Possible role in survival from breast cancer & {$[70]$} \\
\hline & $\mathrm{CT}$ & $\begin{array}{c}51.6 \mathrm{~g} \text { soy protein/day ( } 1.2 \mathrm{mg} \text { genistein/g } \\
\text { protein, and } 0.8 \mathrm{mg} \text { daidzein/g protein), 7-30 } \\
\text { days }\end{array}$ & $\begin{array}{l}\text { Increased markers of cell proliferation in } \\
\text { breast cancer patients }\end{array}$ & {$[71]$} \\
\hline & RCT & $154 \mathrm{mg}$ isoflavone soy protein/day, 3 years & No effects on endometrial cancer & {$[72]$} \\
\hline & $\begin{array}{l}\text { Cohort } \\
\text { multicenter } \\
\text { study }\end{array}$ & $25 \mathrm{~g}$ isoflavone/day, 5 years & No effects on endometrial cancer & [73] \\
\hline & RCT & $80 \mathrm{mg}$ isoflavones/day, 6 weeks & $\begin{array}{c}\text { No changes in PSA in prostate cancer } \\
\text { patients }\end{array}$ & {$[74]$} \\
\hline & $\mathrm{CT}$ & $47 \mathrm{mg}$ isoflavones 3 times/day, 12 months & $\begin{array}{l}\text { Reduced PSA levels in prostate cancer } \\
\text { patients }\end{array}$ & {$[75]$} \\
\hline & CT & $60 \mathrm{mg}$ isoflavones/day, 12 months & $\begin{array}{l}\text { Reduced prostate cancer incidence in } 65 \\
\text { years or older patients }\end{array}$ & {$[76]$} \\
\hline & & Regular soy products consumption & Reduced endometrial cancer risk & \\
\hline
\end{tabular}


TABle 1: Continued.

\begin{tabular}{|c|c|c|c|c|}
\hline $\begin{array}{l}\text { Pharmacological } \\
\text { activity }\end{array}$ & Study type & Dose/type of treatment & Results & References \\
\hline & $\begin{array}{l}\text { Meta- } \\
\text { analysis }\end{array}$ & & & $\begin{array}{l}([77], \\
[78])\end{array}$ \\
\hline & $\begin{array}{c}\text { Meta- } \\
\text { analysis and } \\
\text { CT }\end{array}$ & Regular soy products consumption & Reduced ovarian cancer risk & $\begin{array}{l}([79] \\
[80])\end{array}$ \\
\hline & $\begin{array}{l}\text { Meta- } \\
\text { analysis }\end{array}$ & Regular soy products consumption & $\begin{array}{l}\text { Reduced mortality and recurrence of breast } \\
\text { cancer }\end{array}$ & {$[81]$} \\
\hline & Review & Regular soy products consumption & $\begin{array}{l}\text { Reduced prostate cancer risk in equol } \\
\text { producers }\end{array}$ & {$[82]$} \\
\hline & Review & Regular soy products consumption & $\begin{array}{l}\text { Reduced prostate cancer risk, no differences } \\
\text { in PSA }\end{array}$ & {$[83]$} \\
\hline & Review & Regular isoflavones consumption & $\begin{array}{l}\text { Reduced prostate cancer risk for daidzein, } \\
\text { not for equol }\end{array}$ & {$[84]$} \\
\hline & $\begin{array}{l}\text { Meta- } \\
\text { analysis }\end{array}$ & Regular soy products consumption & Reduced colorectal cancer risk in women & {$[85]$} \\
\hline & Review & Regular isoflavones consumption & No effect on stomach and colorectal cancer & {$[86]$} \\
\hline & Review & Regular phytoestrogen consumption & Possible reduction in colorectal cancer risk & {$[86]$} \\
\hline \multirow{11}{*}{ Cardioprotective } & $\mathrm{CT}$ & Regular soy products consumption & Reduced CVD risk & [87] \\
\hline & $\mathrm{CT}$ & Regular soy products consumption & Reduced myocardial infarction risk & {$[88]$} \\
\hline & $\mathrm{CT}$ & Regular soy products consumption & No changes in CVD mortality & [89] \\
\hline & $\mathrm{CT}$ & Regular phytoestrogen consumption & No changes in CVD risk & {$[90]$} \\
\hline & $\mathrm{CT}$ & Regular isoflavones consumption & Reduced CVD risk & {$[91]$} \\
\hline & $\mathrm{CT}$ & $63 \mathrm{mg}$ daidzein/day, 6 months & $\begin{array}{l}\text { Improved renal function in postmenopausal } \\
\text { women with prehypertension }\end{array}$ & {$[63]$} \\
\hline & RCT & 40-80 mg daidzein/day, 6 months & Reduced TG and uric acid & [43] \\
\hline & Review & Regular soy products consumption & $\begin{array}{l}\text { Reduced platelet aggregation and } \\
\text { atherosclerosis }\end{array}$ & {$[92]$} \\
\hline & $\begin{array}{l}\text { Meta- } \\
\text { analysis }\end{array}$ & Regular soy products consumption & Reduced TC, LDL-C and TG & [93] \\
\hline & Review & Regular soy products consumption & $\begin{array}{l}\text { Improved arterial stiffness and } \\
\text { antiatherogenic effect }\end{array}$ & {$[45]$} \\
\hline & Review & Different phytoestrogen supplementation & $\begin{array}{l}\text { Improved body composition in } \\
\text { postmenopausal women }\end{array}$ & {$[94]$} \\
\hline \multirow{8}{*}{$\begin{array}{l}\text { Antiaging and } \\
\text { cognitive } \\
\text { promotion }\end{array}$} & RCT & $27 \mathrm{~g}$ soy protein/day, 12 weeks & $\begin{array}{l}\text { Decreased gain in muscle strength in older } \\
\text { adults }\end{array}$ & [95] \\
\hline & RCT & $25 \mathrm{~g}$ soy/day, 16 weeks & $\begin{array}{l}\text { Increase in muscle strength in } \\
\text { postmenopausal women }\end{array}$ & {$[96]$} \\
\hline & RCT & $60 \mathrm{mg}$ isoflavones/day, 6 months & Enhanced cognitive performance & {$[97]$} \\
\hline & RCT & $80 \mathrm{mg}$ isoflavones/day, 4 months & $\begin{array}{l}\text { Enhanced cognitive performance and } \\
\text { memory }\end{array}$ & {$[98]$} \\
\hline & $\mathrm{CT}$ & Regular phytoestrogen consumption & Improved verbal memory & [99] \\
\hline & RCT & $\begin{array}{l}52 \mathrm{mg} \text { genistein }+36 \mathrm{mg} \text { daidzein }+3 \mathrm{mg} \\
\text { glycitein daily, } 2.5 \text { years }\end{array}$ & Possibly improved visual memory & {$[100]$} \\
\hline & RCT & $100 \mathrm{mg}$ isoflavones/day, 6 months & $\begin{array}{l}\text { No beneficial effects for Alzheimer's disease } \\
\text { patients }\end{array}$ & {$[101]$} \\
\hline & $\mathrm{CT}$ & $50 \mathrm{mg}$ phytoSERM/day, 12 weeks & Possible enhancement of cognitive activity & {$[102]$} \\
\hline \multirow{2}{*}{ Thyroid function } & $\mathrm{CT}$ & $80-120 \mathrm{mg}$ isoflavones/day, 2 years & No changes in thyroid function & [103] \\
\hline & $\mathrm{CT}$ & $80 \mathrm{mg}$ isoflavones/day, 3 months & No changes in thyroid function & {$[104]$} \\
\hline \multirow{2}{*}{ Antidiabetic } & $\mathrm{CT}$ & Regular isoflavones consumption & Decreased type 2 diabetes risk & [105] \\
\hline & RCT & $40 \mathrm{~g}$ soy protein/day, 57 days & & [106] \\
\hline
\end{tabular}


TABLE 1: Continued.

\begin{tabular}{|c|c|c|c|c|}
\hline $\begin{array}{l}\text { Pharmacological } \\
\text { activity }\end{array}$ & Study type & Dose/type of treatment & Results & References \\
\hline & & & $\begin{array}{l}\text { No beneficial effects for glycemic control in } \\
\text { diabetic patients }\end{array}$ & \\
\hline & RCT & $50 \mathrm{mg}$ daidzein/day, 12,24 weeks & $\begin{array}{l}\text { No beneficial effects for glycemic control or } \\
\text { insulin sensitivity in diabetes patients }\end{array}$ & {$[107]$} \\
\hline & RCT & $10 \mathrm{mg}$ equol/day, 12 weeks & $\begin{array}{c}\text { Possibly improved glycemia control in } \\
\text { overweight patients }\end{array}$ & {$[108]$} \\
\hline
\end{tabular}

CT: clinical trial; LDL: low density lipoprotein; RCT: randomized controlled trial; SR: systematic review; TC: total cholesterol; TG: triglycerides.

postmenopausal women resulted in an increased bone density and improvement in bone resorption and formation biomarkers [52, 53]. Abdi et al. [57] reported in their systematic review that isoflavones may improve bone health and prevent mineral density loss in menopausal women.

Estrogens also exert direct effects on calcium homeostasis through ER-independent mechanisms. In fact, a correlation between estradiol and calcium levels has been described and inversely correlated with osteoporosis-associated fractures in humans [113]. Recently, Lu et al. [54] reported no changes in serum calcium levels with isoflavone pills uptake, containing $60 \mathrm{mg}$ genistein and daidzein, 5 days/week for 2 years. However, a potential association was proposed between daidzein urinary excretion and serum calcium and chloride levels.

Pawlowski et al. [55] showed that a treatment with $105.23 \mathrm{mg}$ total isoflavones/day, including genistein, daidzein, and glycitein, led to an increase in calcium retention in bones, although no differences were reported when equol producers and nonproducers were compared. On the other hand, Nayeem et al. [56] found a correlation between urinary isoflavone levels and decreased mineral density in women with low calcium levels.

Several studies have analyzed the effect of daidzein and equol in menopausal symptom reduction in women, like hot flashes and muscle and joint pain $[2,58]$. Supplementation with $10 \mathrm{mg}$ of equol 3 times/day reduced symptoms like anxiety, depression, and fatigue in postmenopausal women [59]. Other studies have also shown an improvement in some symptoms, including hot flash frequency, muscle stiffness, sweating, and renal function [58, 60, 63]. Interestingly, in several studies, equol-producing women showed a decrease in anxiety [59] and hot flash scores, as well as in sweating and fatigue [61], and hot flashes intensity [62] compared to equol nonproducing women. However, other studies have reported no benefits of daidzein or isoflavone supplementation in menopausal symptom reduction [64].

To address such controversy, some meta-analyses have been performed. Chen et al. [65] reported no evidence of improvement in the Kupperman Index, a questionnaire on menopausal symptoms, for women under a phytoestrogen treatment. However, based on the data obtained, the authors revealed that phytoestrogens seem to reduce hot flash frequency without having any marked side effects. Another meta-analysis reported such reduction in hot flashes with isoflavones, as well as other beneficial effects on vascular health, although they were not able to improve the urogeni- tal symptoms [66]. Thus, taken together, such controversial results on the potential effects of daidzein and other isoflavones are presumably due to a lack of standardized protocol treatments, since different doses, study periods, supplement composition, and methods to determine the outcomes are used. Another proposed reason for this discrepancy in results is that most studies fail to distinguish equol producers from nonproducers and to determine the levels of free, unconjugated equol, which is presumably the main effector [114].

3.3. Daidzein and Cancer. Incidence and mortality rates of hormone-dependent tumors, such as breast, prostate, and ovarian cancer are considerably lower in Asia when compared to Western countries. This fact has been attributed to the higher soy isoflavone consumption in the Asian population, which has increased the interest in soy isoflavones for both prevention and treatment of such types of cancers [115]. However, some issues have yet to be resolved, such as the bioavailability of these compounds in the target tissue. Most studies show a dual effect of isoflavones on cancer depending on their concentration. Thus, tissue distribution and concentration must be determined to understand whether daidzein or other compounds may have beneficial or harmful effects in cancer [116]. For instance, Bolca et al. [23] analyzed the concentration of isoflavones in normal breast tissue following a dietary intervention increasing isoflavone intake, and they found that isoflavones may reach significant levels in breast to elicit a beneficial effect.

Several in vitro studies have described an anticancer effect for daidzein in different types of tumors [117-121]. Among the mechanisms described, daidzein was reported to induce apoptosis and cell cycle arrest in the SKOV3 ovarian cancer cell line [122] or induce epigenetic changes in vivo [123]. Furthermore, daidzein could modulate long noncoding RNA (lncRNA) expression in some cancer types, as several isoflavones have been reported to target these molecules [124].

The impact of soy on breast carcinogenesis has been widely evaluated. A meta-analysis conducted by Chi et al. [81] revealed that soy isoflavones may be associated with a lower incidence of breast cancer and that ER-negative breast cancer patients could benefit from an isoflavone supplementation. A decrease in breast cancer recurrence has been described for both soy consumption [67] and daidzein supplementation [68] in postmenopausal women. Interestingly, soy consumption has also been associated with a decreased 
expression of HER2/neu and PCNA in tumors, directly related to a more proliferative, malignant tumor phenotype [125]. On the other hand, Shike et al. [71] described a gene signature associated with higher cell proliferation in women with breast cancer with a supplement of soy protein, warning on the possible counterproductive effects of soy supplementation for breast cancer patients. Nevertheless, the American Association for Cancer Research recommends soy consumption in women, including those diagnosed with breast cancer [2]. In a meta-analysis, isoflavones showed a nonsignificative association with a decreased risk of breast cancer, as well as with either individual compounds as genistein, daidzein, and glycitein [69]. Soy isoflavone consumption has also been associated with a reduced risk of endometrial $[77,78]$ and ovarian cancer $[79,80]$. However, other studies have found no effects of soy administration regarding endometrial health and cancer [72, 73]. In a recent review with meta-analysis, the authors suggested that phytoestrogens may play a role in breast cancer disease, although in other cancers, the evidence is too limited to draw this conclusion [70].

Prostate cancer incidence and mortality are significantly higher among North American and European men compared to Asian men. This difference has been attributed, in part, to the ability to produce equol, which is substantially higher among the Asian population [82]. Some studies have described a lower prostate cancer risk with soy isoflavone intake, although no changes in prostate-specific antigen (PSA) levels were observed under short-term treatments [2, $8,74-76,83,126-128]$. Zhang et al. [84] reported that while total isoflavones and equol were not correlated with prostate cancer risk, daidzein and other isoflavones could reduce the risk of developing this type of cancer.

Epidemiological data suggest that soy intake may have benefits for other types of cancer. For instance, phytoestrogen administration may be associated with a lower risk of colorectal cancer $[85,86]$. Phytoestrogens have been described to increase the expression of ER $\beta$ in normal colonic mucosa in humans [129], which could explain the protection against this type of cancer. However, since soy consumption is usually associated with healthier diet choices, this risk reduction may not be entirely due to daidzein and other soy components. Interestingly, Jiang et al. [34] detected that only in case-control and not in cohort studies the risk of colorectal cancer seemed to be reduced with isoflavone administration.

3.4. Daidzein and Cardiovascular Diseases. In animal models, daidzein was able to reduce platelet aggregation and nitric oxide production, suggesting a cardioprotective effect [130]. In this regard, daidzein has been reported to interfere with the inducible nitric oxide synthase (iNOS) expression pathway resulting in the downregulation of this enzyme (Figure 3) [131].

The first reports on the beneficial effects of soy products on human CV health were made more than two decades ago, with a meta-analysis showing that soy protein intake decreased total cholesterol (TC) and low-density lipoprotein- (LDL-) cholesterol levels [93]. Isoflavones have been found to enhance endothelial function and limit atherosclerosis progression [92], as well as lower blood pressure, improve lipid profile, and reduce oxidative stress and inflammation [132]. Daidzein administration only lowered serum triglycerides (TG) and uric acid, while the rest of the lipid profile and glucose remained unchanged. Interestingly, participants with a specific ER genotype were those who most benefit from this intervention [43]. Furthermore, equol has shown potential as an antiatherogenic agent and could prevent coronary heart disease [45].

Controversial results have been described in epidemiological studies analyzing the effects of isoflavones on coronary heart disease. The Shanghai Women's Health Study [87] and a Japanese cohort study [88] reported an inverse correlation between heart disease and dietary soy intake, while the Singapore Chinese Health Study [89] and the European Prospective study Into Cancer and Nutrition [90] showed no association. Zhang et al. [91] described a significant inverse correlation between coronary heart diseases and equol, but no effects were stated to soy isoflavones or their metabolites. On the other hand, another report suggested that the benefit for cardiovascular health is only seen in equol producers after 6 months of soy supplementation but not with the use of purified daidzein [63].

Finally, a meta-analysis performed by Glisic et al. [94] analyzed the effect of phytoestrogen on body weight and body composition in postmenopausal women. Phytoestrogen administration did not produce any changes in these parameters, although those participants with preexisting conditions such as diabetes or hyperlipidemia suffered an increase in body weight. Furthermore, daidzein could be associated with nonbeneficial effects in body composition. Miller et al. [133] suggested that gut microbiota could influence the incidence of obesity, as they reported that both peri- and postmenopausal women who did not produce $O$ DMA metabolite showed higher rates of overweight and obesity.

\subsection{Effects of Daidzein on Aging and Cognitive Activities.} Aging is usually associated with a decline in muscle mass and strength. Thomson et al. [95] analyzed the effects of soy intake on training resistance in older adults. Interestingly, they reported that those participants with soy protein supplementation did not gain as much muscle strength when compared to adults with regular protein or dairy protein intake. On the other hand, Orsatti et al. [96] reported a significant increase in muscle strength after 16 weeks of training resistance and soy supplementation in postmenopausal women.

Another hallmark of aging is a mild cognitive decline regarding learning, memory, and perception. The incidence of neurodegenerative diseases and dementia is also rapidly growing among the elderly population. Some studies have proposed estrogen therapy as a treatment for improving memory and preventing Alzheimer's disease in postmenopausal women [134]. Likewise, isoflavone administration may also improve cognitive functions and memory [97-100]. However, although a protective effect against Alzheimer's disease has been described in mice [135], following 


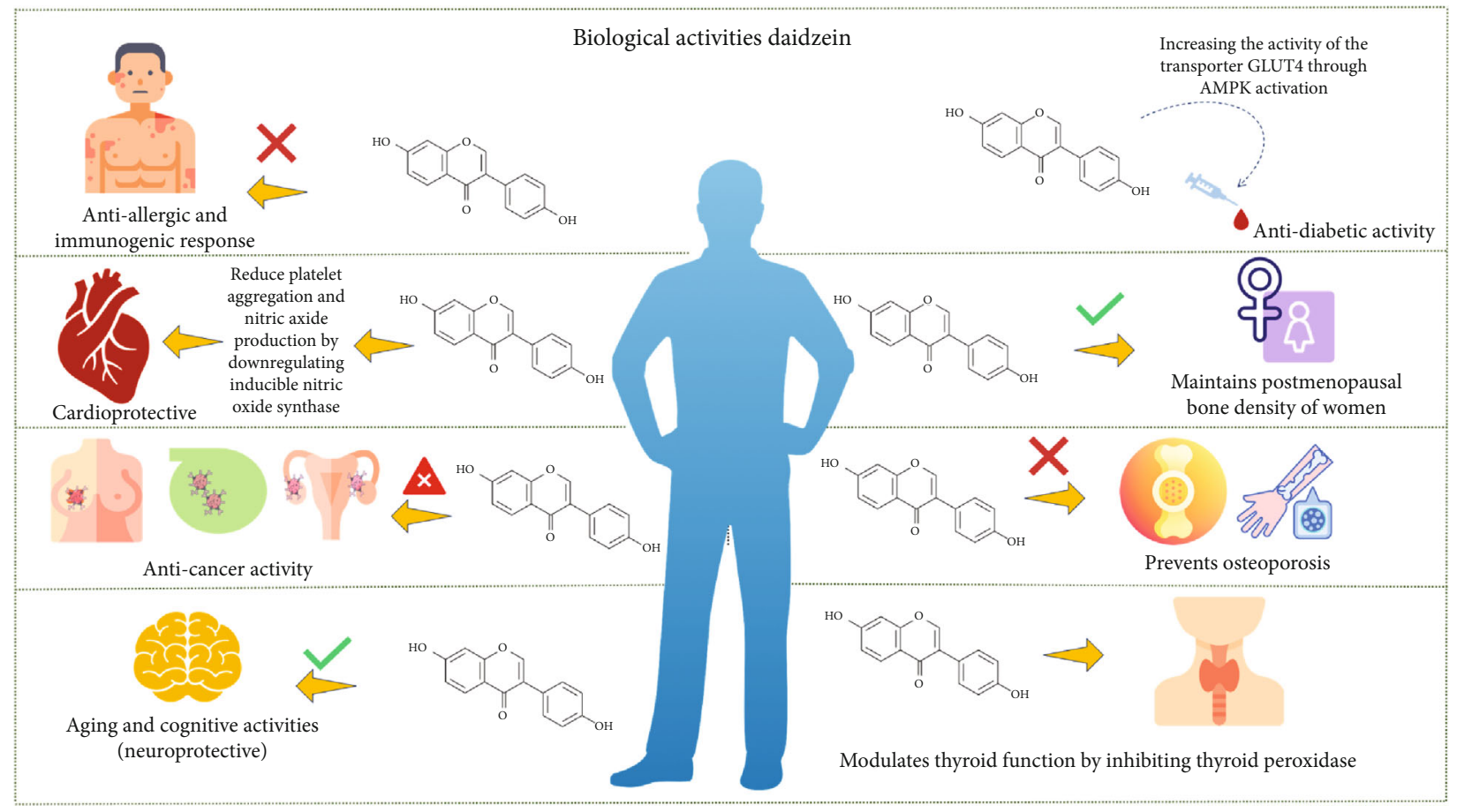

Figure 3: Various biological activities of the daidzein.

analysis of isoflavone supplementation effects in Alzheimer's disease patients, Gleason et al. [101] concluded that there were no significant benefits. Lately, Hernandez et al. [136] and Schneider et al. [102] tested PhytoSERM for 12 weeks in perimenopausal women, a mixture composed of genistein, daidzein, and equol. With a daily dose of $50 \mathrm{mg}$, the participants declared a reduction in menopausal symptoms and a better cognitive function, with no associated side effects. In this regard, more studies increasing the number of participants and analyzing the effects of PhytoSERM on cognitive decline are still undergoing.

3.6. Effects of Daidzein on Thyroid Function. Daidzein and other isoflavones are known enzymatic inhibitors and, theoretically, they may interfere with thyroid function as they inhibit thyroid peroxidase. However, several studies were measured thyroid function, and no special impact of isoflavones was found [103, 137]. Sosvorová et al. [104] confirmed that both genistein and daidzein are targets of thyroid peroxidase by detection of iodinated derivates of these isoflavones in human urine, although no effects were described in free thyroid hormones levels. Thus, there is no evidence that daidzein consumption could be harmful to thyroid gland disorders.

3.7. Daidzein and Diabetes. Isoflavones have also been studied for the treatment of diabetes. Interestingly, these compounds have the ability to modulate gut microbiota, which is altered in diabetes, and their potential use to prevent and manage this disease is currently being analyzed [138]. Some studies suggest that daidzein could enhance glucose and lipid metabolism, regulating glycemia and TC levels in animal models $[139,140]$ and increasing the activity of the transporter GLUT4 through AMPK activation [141]. Furthermore, the detection of equol in urine has been associated with a reduction in type 2 diabetes incidence among the Chinese population [105]. However, Gobert et al. [106] reported that isoflavones had no significant effect on glycemic control in patients with type 2 diabetes, and Ye et al. [107] found that daidzein improved neither insulin sensitivity nor glycemia following 6 months of treatment. Nevertheless, body weight control can be helpful for diabetes management. In this regard, isoflavones have shown potential to reduce fat accumulation and improve insulin resistance in animals [2, $142,143]$. Similarly, isoflavones could help in weight loss in humans $[2,108,144]$, as these compounds have shown higher lipolytic potential [145]. Various biological activities of daidzein are shown in Figure 3.

3.8. Soy and Soy-Derived Metabolites in Children. Phytoestrogens may theoretically interfere with ER signaling in the developing brain of children or produce gut dysbiosis, although these results are controversial [146]. Soy-based formulas are often used for infants under certain circumstances, such as allergy and intolerance to milk, lactose intolerance, or galactosemia. Vandenplas et al. [147] evaluated the safety of these formulas and found that, although the levels of genistein and daidzein were higher in formula-fed infants, no harmful effects regarding anthropometric growth, immunity, cognition, or endocrine functions were found.

\section{Conclusions and Future Perspectives}

As mentioned before, daidzein has potent antioxidant and estrogenic activities, which has led to a wide interest in 
developing a functional food containing this compound. In adults, daidzein and other phytoestrogens are welltolerated and have low levels of toxicity, while in infants, there are reports concerning their harmful effects. In the last years, there has been an increase in the consumption of soy products. For a better understanding of the properties of such soy products, it would be necessary to indicate, in addition to the quantity, the type of isoflavones that these products contain. Food processing technologies could affect both retention and distribution of different isoflavone isomers present in soy products. Both transformation and/or loss of some isoflavones, especially genistein and daidzein, may affect the nutraceutical characteristics of these soy products.

Although some of the benefits of isoflavones such as daidzein have been demonstrated, the side effects (for example the potential fertility problems among male humans) of long-lasting high consumption of these soy products need to be studied in a more in-depth way. In fact, clinical trial data are conflicting, showing both negative and positive effects of daidzein on human health. That is why a correct standardization and documentation of these clinical trials is essential to advance in the study of daidzein's beneficial effects on human health. Despite being possible to control all the independent variables in clinical trials, the ability of each individual to metabolize daidzein closely depends on individual's microbiota composition, the ability of this microbiota to assimilate the dose administered, and the different bioavailability of daidzein that could influence the data heterogeneity.

In the future, the use of genetic screening techniques could represent a great advance in personalized medicine. One of the uses of such techniques could be the assessment of the genetic predisposition of an individual to metabolize daidzein, which could initially help to select comparable groups for clinical trials and then filter the possible recipients of a treatment with daidzein, depending on individual's ability to metabolize this phytoestrogen. Moreover, the consumption of soy-rich products should be monitored by physicians, especially in cases of diseases for which daidzein is known to play an essential role, such as breast cancer [148].

\section{Data Availability}

The data used to support the findings of this study are available from the corresponding author upon request.

\section{Conflicts of Interest}

The authors declare that they have no conflicts of interest.

\section{Acknowledgments}

N.M. acknowledges the Portuguese Foundation for Science and Technology under the Horizon 2020 Program (PTDC/PSI-GER/28076/2017). M. T-M was funded by a grant from the Programa Postdoctoral Margalida ComasComunidad Autónoma de las Islas Baleares (PD/050/2020). The authors also acknowledge that some of the icons used in figures are adapted from Flaticon.

\section{References}

[1] D. Prakash and C. Gupta, "Phytopharmaceutical applications of nutraceutical and functional foods," in Recent Advances in Drug Delivery Technology, IGI Global, Hershey, PA, USA, 2017.

[2] K. Zaheer and A. M. Humayoun, "An updated review of dietary isoflavones: nutrition, processing, bioavailability and impacts on human health," Critical Reviews in Food Science and Nutrition, vol. 57, no. 6, pp. 1280-1293, 2017.

[3] A. Cassidy, "Potential risks and benefits of phytoestrogenrich diets," International Journal for Vitamin and Nutrition Research, vol. 73, no. 2, pp. 120-126, 2003.

[4] S. A. Bingham, C. Atkinson, J. Liggins, L. Bluck, and A. Coward, "Phyto-oestrogens: where are we now?" British Journal of Nutrition, vol. 79, no. 5, pp. 393-406, 1998.

[5] K. Dwiecki, G. Neunert, P. Polewski, and K. Polewski, "Antioxidant activity of daidzein, a natural antioxidant, and its spectroscopic properties in organic solvents and phosphatidylcholine liposomes," Journal of Photochemistry and Photobiology B: Biology, vol. 96, no. 3, pp. 242-248, 2009.

[6] Breast Cancer and Environment Research Center, Phytoestrogen daidzein, BCERC COTC Fact Sheet, 2007.

[7] N. Sathyamoorthy and T. T. Wang, "Differential effects of dietary phyto-oestrogens daidzein and equol on human breast cancer MCF-7 cells," European Journal of Cancer, vol. 33, no. 14, pp. 2384-2389, 1997.

[8] M. Adjakly, M. Ngollo, J. P. Boiteux, Y. J. Bignon, L. Guy, and D. Bernard-Gallon, "Genistein and daidzein: different molecular effects on prostate cancer," Anticancer Research, vol. 33, no. 1, pp. 39-44, 2013.

[9] D. C. Vitale, C. Piazza, B. Melilli, F. Drago, and S. Salomone, "Isoflavones: estrogenic activity, biological effect and bioavailability," European Journal of Drug Metabolism and Pharmacokinetics, vol. 38, no. 1, pp. 15-25, 2013.

[10] M. Masilamani, J. Wei, and H. A. Sampson, "Regulation of the immune response by soybean isoflavones," Immunologic Research, vol. 54, no. 1-3, pp. 95-110, 2012.

[11] F. H. Lo, N. K. Mak, and K. N. Leung, "Studies on the antitumor activities of the soy isoflavone daidzein on murine neuroblastoma cells," Biomedicine \& Pharmacotherapy, vol. 61, no. 9, pp. 591-595, 2007.

[12] B. Klejdus, R. Mikelová, J. Petrlová et al., "Evaluation of isoflavone aglycon and glycoside distribution in soy plants and soybeans by fast column high-performance liquid chromatography coupled with a diode-array detector," Journal of Agricultural and Food Chemistry, vol. 53, no. 15, pp. 58485852, 2005.

[13] P. A. Murphy, T. Song, G. Buseman et al., "Isoflavones in retail and institutional soy foods," Journal of Agricultural and Food Chemistry, vol. 47, no. 7, pp. 2697-2704, 1999.

[14] X. Xu, H. J. Wang, P. A. Murphy, L. Cook, and S. Hendrich, "Daidzein is a more bioavailable soymilk isoflavone than is genistein in adult women," The Journal of Nutrition, vol. 124, no. 6, pp. 825-832, 1994.

[15] K. D. Setchell, N. M. Brown, P. Desai et al., "Bioavailability of pure isoflavones in healthy humans and analysis of commercial soy isoflavone supplements," The Journal of Nutrition, vol. 131, no. 4, pp. 1362s-1375s, 2001.

[16] A. J. Day, M. S. DuPont, S. Ridley et al., "Deglycosylation of flavonoid and isoflavonoid glycosides by human small 
intestine and liver beta-glucosidase activity," FEBS Letters, vol. 436, no. 1, pp. 71-75, 1998.

[17] C. R. Cederroth, C. Zimmermann, and S. Nef, "Soy, phytoestrogens and their impact on reproductive health," Molecular and Cellular Endocrinology, vol. 355, no. 2, pp. 192-200, 2012.

[18] B. Mayo, L. Vazquez, and A. B. Florez, "Equol: a bacterial metabolite from the daidzein isoflavone and its presumed beneficial health effects," Nutrients, vol. 16, p. 11, 2019.

[19] P. B. Grace, J. I. Taylor, Y. L. Low et al., "Phytoestrogen concentrations in serum and spot urine as biomarkers for dietary phytoestrogen intake and their relation to breast cancer risk in European prospective investigation of cancer and nutrition-norfolk," Cancer Epidemiology and Prevention Biomarkers, vol. 13, pp. 698-708, 2004.

[20] S. E. Kulling, D. M. Honig, and M. Metzler, "Oxidative metabolism of the soy isoflavones daidzein and genistein in humans in vitro and in vivo," Journal of Agricultural and Food Chemistry, vol. 49, no. 6, pp. 3024-3033, 2001.

[21] S. T. Soukup, J. Helppi, D. R. Müller et al., "Phase II metabolism of the soy isoflavones genistein and daidzein in humans, rats and mice: a cross-species and sex comparison," Archives of Toxicology, vol. 90, no. 6, pp. 1335-1347, 2016.

[22] A. A. Franke, J. F. Lai, and B. M. Halm, "Absorption, distribution, metabolism, and excretion of isoflavonoids after soy intake," Archives of Biochemistry and Biophysics, vol. 559, pp. 24-28, 2014.

[23] S. Bolca, M. Urpi-Sarda, P. Blondeel et al., "Disposition of soy isoflavones in normal human breast tissue," The American Journal of Clinical Nutrition, vol. 91, no. 4, pp. 976-984, 2010.

[24] S. Hüser, S. Guth, H. G. Joost et al., "Effects of isoflavones on breast tissue and the thyroid hormone system in humans: a comprehensive safety evaluation," Archives of Toxicology, vol. 92, no. 9, pp. 2703-2748, 2018.

[25] D. Pugazhendhi, K. A. Watson, S. Mills, N. Botting, G. S. Pope, and P. D. Darbre, "Effect of sulphation on the oestrogen agonist activity of the phytoestrogens genistein and daidzein in MCF-7 human breast cancer cells," The Journal of Endocrinology, vol. 197, no. 3, pp. 503-515, 2008.

[26] R. A. King and D. B. Bursill, "Plasma and urinary kinetics of the isoflavones daidzein and genistein after a single soy meal in humans," The American Journal of Clinical Nutrition, vol. 67 , no. 5, pp. 867-872, 1998.

[27] S. R. Shelnutt, C. O. Cimino, P. A. Wiggins, and T. M. Badger, "Urinary pharmacokinetics of the glucuronide and sulfate conjugates of genistein and daidzein," Cancer Epidemiology and Prevention Biomarkers, vol. 9, pp. 413-419, 2000.

[28] A. J. Day, F. J. Cañada, J. C. Díaz et al., "Dietary flavonoid and isoflavone glycosides are hydrolysed by the lactase site of lactase phlorizin hydrolase," FEBS Letters, vol. 468, no. 2-3, pp. 166-170, 2000.

[29] M. K. Piskula, "Soy isoflavone conjugation differs in fed and food-deprived rats," The Journal of Nutrition, vol. 130, no. 7, pp. 1766-1771, 2000.

[30] C. E. Rüfer, A. Bub, J. Möseneder, P. Winterhalter, M. Stürtz, and S. E. Kulling, "Pharmacokinetics of the soybean isoflavone daidzein in its aglycone and glucoside form: a randomized, double-blind, crossover study," The American Journal of Clinical Nutrition, vol. 87, no. 5, pp. 1314-1323, 2008.

[31] T. Izumi, M. K. Piskula, S. Osawa et al., "Soy isoflavone aglycones are absorbed faster and in higher amounts than their glucosides in humans," The Journal of Nutrition, vol. 130, no. 7, pp. 1695-1699, 2000.

[32] A. Crozier, D. Del Rio, and M. N. Clifford, "Bioavailability of dietary flavonoids and phenolic compounds," Molecular Aspects of Medicine, vol. 31, no. 6, pp. 446-467, 2010.

[33] K. D. Setchell, M. S. Faughnan, T. Avades et al., "Comparing the pharmacokinetics of daidzein and genistein with the use of 13C-labeled tracers in premenopausal women," The American Journal of Clinical Nutrition, vol. 77, no. 2, pp. 411-419, 2003.

[34] R. Jiang, A. Botma, A. Rudolph, A. Hüsing, and J. ChangClaude, "Phyto-oestrogens and colorectal cancer risk: a systematic review and dose-response meta-analysis of observational studies," British Journal of Nutrition, vol. 116, no. 12, pp. 2115-2128, 2016.

[35] S. Watanabe, M. Yamaguchi, T. Sobue et al., "Pharmacokinetics of soybean isoflavones in plasma, urine and feces of men after ingestion of $60 \mathrm{~g}$ baked soybean powder (kinako)," The Journal of Nutrition, vol. 128, no. 10, pp. 1710-1715, 1998.

[36] A. Cassidy, J. E. Brown, A. Hawdon et al., "Factors affecting the bioavailability of soy isoflavones in humans after ingestion of physiologically relevant levels from different soy foods," The Journal of Nutrition, vol. 136, no. 1, pp. 45-51, 2006.

[37] J. H. Cummings and G. T. Macfarlane, "The control and consequences of bacterial fermentation in the human colon," Journal of Applied Bacteriology, vol. 70, no. 6, pp. 443-459, 1991.

[38] C. Piazza, M. G. Privitera, B. Melilli et al., "Influence of inulin on plasma isoflavone concentrations in healthy postmenopausal women," The American Journal of Clinical Nutrition, vol. 86, no. 3, pp. 775-780, 2007.

[39] J. Maubach, H. T. Depypere, J. Goeman et al., "Distribution of soy-derived phytoestrogens in human breast tissue and biological fluids," Obstetrics and Gynecology, vol. 103, 5, Part 1, pp. 892-898, 2004.

[40] Y. Peng, Y. Shi, H. Zhang, Y. Mine, and R. Tsao, “Antiinflammatory and anti-oxidative activities of daidzein and its sulfonic acid ester derivatives," Journal of Functional Foods, vol. 35, pp. 635-640, 2017.

[41] the International Natural Product Sciences Taskforce, A. G. Atanasov, S. B. Zotchev, V. M. Dirsch, and C. T. Supuran, "Natural products in drug discovery: advances and opportunities," Nature Reviews Drug Discovery, vol. 20, no. 3, pp. 200-216, 2021.

[42] D. J. Newman and G. M. Cragg, "Natural products as sources of new drugs over the nearly four decades from 01/1981 to 09/2019," Journal of Natural Products, vol. 83, no. 3, pp. 770-803, 2020.

[43] Y. Qin, F. Shu, Y. Zeng et al., "Daidzein supplementation decreases serum triglyceride and uric acid concentrations in hypercholesterolemic adults with the effect on triglycerides being greater in those with the GA compared with the GG genotype of ESR- $\beta$ RsaI," The Journal of Nutrition, vol. 144, no. 1, pp. 49-54, 2014.

[44] L. J. Lu and K. E. Anderson, "Sex and long-term soy diets affect the metabolism and excretion of soy isoflavones in humans," The American Journal of Clinical Nutrition, vol. 68, no. 6, pp. 1500s-1504s, 1998.

[45] A. Sekikawa, M. Ihara, O. Lopez et al., "Effect of S-equol and soy isoflavones on heart and brain," Current Cardiology Reviews, vol. 15, no. 2, pp. 114-135, 2019. 
[46] N. M. Brown, S. L. Galandi, S. S. Summer et al., "S-(-)equol production is developmentally regulated and related to early diet composition," Nutrition Research, vol. 34, no. 5, pp. 401-409, 2014.

[47] M. C. Kruger, C. Middlemiss, S. Katsumata, Y. Tousen, and Y. Ishimi, "The effects of green kiwifruit combined with isoflavones on equol production, bone turnover and gut microflora in healthy postmenopausal women," Asia Pacific Journal of Clinical Nutrition, vol. 27, no. 2, pp. 347-358, 2018.

[48] Y. Tousen, M. Uehara, F. Abe, Y. Kimira, and Y. Ishimi, "Effects of short-term fructooligosaccharide intake on equol production in Japanese postmenopausal women consuming soy isoflavone supplements: a pilot study," Nutrition Journal, vol. 12, no. 1, p. 127, 2013.

[49] C. Iino, T. Shimoyama, K. Iino et al., "Daidzein intake is associated with equol producing status through an increase in the intestinal bacteria responsible for equol production," Nutrients, vol. 11, no. 2, p. 433, 2019.

[50] Y. Miyake, S. Sasaki, Y. Ohya et al., "Soy, isoflavones, and prevalence of allergic rhinitis in Japanese women: The Osaka Maternal and Child Health Study," Journal of Allergy and Clinical Immunology, vol. 115, no. 6, pp. 1176-1183, 2005.

[51] L. J. Smith, R. Kalhan, R. A. Wise et al., "Effect of a soy isoflavone supplement on lung function and clinical outcomes in patients with poorly controlled asthma: a randomized clinical trial," JAMA, vol. 313, no. 20, pp. 2033-2043, 2015.

[52] N. Ö. Turhan, F. Bolkan, C. Í. Duvan, and Y. Ardicoglu, “The effect of isoflavones on bone mass and bone remodelling markers in postmenopausal women," Turkish Journal of Medical Sciences, vol. 38, pp. 145-152, 2008.

[53] H. Lee, R. Choue, and H. Lim, "Effect of soy isoflavones supplement on climacteric symptoms, bone biomarkers, and quality of life in Korean postmenopausal women: a randomized clinical trial," Nutrition Research and Practice, vol. 11, no. 3, pp. 223-231, 2017.

[54] L.-J. W. Lu, N.-W. Chen, F. Nayeem et al., "Novel effects of phytoestrogenic soy isoflavones on serum calcium and chloride in premenopausal women: a 2-year double-blind, randomized, placebo-controlled study," Clinical Nutrition, vol. 37, no. 6, pp. 1862-1870, 2018.

[55] J. W. Pawlowski, B. R. Martin, G. P. McCabe et al., "Impact of equol-producing capacity and soy-isoflavone profiles of supplements on bone calcium retention in postmenopausal women: a randomized crossover trial," The American Journal of Clinical Nutrition, vol. 102, no. 3, pp. 695-703, 2015.

[56] F. Nayeem, N. W. Chen, M. Nagamani, K. E. Anderson, and L. W. Lu, "Daidzein and genistein have differential effects in decreasing whole body bone mineral density but had no effect on hip and spine density in premenopausal women: a 2-year randomized, double-blind, placebo-controlled study," Nutrition Research, vol. 68, pp. 70-81, 2019.

[57] F. Abdi, Z. Alimoradi, P. Haqi, and F. Mahdizad, "Effects of phytoestrogens on bone mineral density during the menopause transition: a systematic review of randomized, controlled trials," Climacteric, vol. 19, no. 6, pp. 535-545, 2016.

[58] B. H. Jenks, S. Iwashita, Y. Nakagawa et al., "A pilot study on the effects of S-equol compared to soy isoflavones on menopausal hot flash frequency," Journal of Women's Health, vol. 21, no. 6, pp. 674-682, 2012.

[59] N. Ishiwata, M. K. Melby, S. Mizuno, and S. Watanabe, "New equol supplement for relieving menopausal symptoms: ran- domized, placebo-controlled trial of Japanese women," Menopause, vol. 16, no. 1, pp. 141-148, 2009.

[60] T. Aso, "Equol improves menopausal symptoms in Japanese women.," The Journal of Nutrition, vol. 140, no. 7, pp. 1386s-1389s, 2010.

[61] H. J. Jou, S. C. Wu, F. W. Chang, P. Y. Ling, K. S. Chu, and W. H. Wu, "Effect of intestinal production of equol on menopausal symptoms in women treated with soy isoflavones," International Journal of Gynecology \& Obstetrics, vol. 102, no. 1, pp. 44-49, 2008.

[62] S. L. Crawford, E. A. Jackson, L. Churchill, J. W. Lampe, K. Leung, and J. K. Ockene, "Impact of dose, frequency of administration, and equol production on efficacy of isoflavones for menopausal hot flashes: a pilot randomized trial," Menopause, vol. 20, no. 9, pp. 936-945, 2013.

[63] Z. M. Liu, S. C. Ho, Y. M. Chen, N. Tang, and J. Woo, "Effect of whole soy and purified isoflavone daidzein on renal function-a 6-month randomized controlled trial in equolproducing postmenopausal women with prehypertension," Clinical Biochemistry, vol. 47, no. 13-14, pp. 1250-1256, 2014.

[64] A. E. Ribeiro, N. E. S. Monteiro, A. V. G. Moraes, L. H. CostaPaiva, and A. O. Pedro, "Can the use of probiotics in association with isoflavone improve the symptoms of genitourinary syndrome of menopause? Results from a randomized controlled trial," Menopause, vol. 26, no. 6, pp. 643-652, 2018.

[65] M. N. Chen, C. C. Lin, and C. F. Liu, "Efficacy of phytoestrogens for menopausal symptoms: a meta-analysis and systematic review," Climacteric, vol. 18, no. 2, pp. 260-269, 2015.

[66] L. R. Chen, N. Y. Ko, and K. H. Chen, "Isoflavone supplements for menopausal women: a systematic review," Nutrients, vol. 11, no. 11, p. 2649, 2019.

[67] N. Guha, M. L. Kwan, C. P. Quesenberry, E. K. Weltzien, A. L. Castillo, and B. J. Caan, "Soy isoflavones and risk of cancer recurrence in a cohort of breast cancer survivors: the life after cancer epidemiology study," Breast Cancer Research and Treatment, vol. 118, no. 2, pp. 395-405, 2009.

[68] X. O. Shu, Y. Zheng, H. Cai et al., "Soy food intake and breast cancer survival," JAMA, vol. 302, no. 22, pp. 2437-2443, 2009.

[69] G. Grosso, J. Godos, R. Lamuela-Raventos et al., "A comprehensive meta-analysis on dietary flavonoid and lignan intake and cancer risk: level of evidence and limitations," Molecular Nutrition \& Food Research, vol. 61, no. 4, 2017.

[70] A. Micek, J. Godos, T. Brzostek et al., "Dietary phytoestrogens and biomarkers of their intake in relation to cancer survival and recurrence: a comprehensive systematic review with meta-analysis," Nutrition Reviews, vol. 79, no. 1, pp. 42-65, 2021.

[71] M. Shike, A. S. Doane, L. Russo et al., "The effects of soy supplementation on gene expression in breast cancer: a randomized placebo-controlled study," JNCI: Journal of the National Cancer Institute, vol. 106, no. 9, 2014.

[72] A. M. Quaas, N. Kono, W. J. Mack et al., "Effect of isoflavone soy protein supplementation on endometrial thickness, hyperplasia, and endometrial cancer risk in postmenopausal women: a randomized controlled trial," Menopause, vol. 20, no. 8, pp. 840-844, 2013.

[73] S. Budhathoki, M. Iwasaki, N. Sawada et al., "Soy food and isoflavone intake and endometrial cancer risk: the Japan Public Health Center-based prospective study," BJOG, vol. 122, no. 3, pp. 304-311, 2015. 
[74] J. M. Hamilton-Reeves, S. Banerjee, S. K. Banerjee et al., "Short-term soy isoflavone intervention in patients with localized prostate cancer: a randomized, double-blind, placebo-controlled trial," PLoS One, vol. 8, no. 7, article e68331, 2013.

[75] J. M. Pendleton, W. W. Tan, S. Anai et al., "Phase II trial of isoflavone in prostate-specific antigen recurrent prostate cancer after previous local therapy," BMC Cancer, vol. 8, no. 1, p. ???, 2008.

[76] N. Miyanaga, H. Akaza, S. Hinotsu et al., "Prostate cancer chemoprevention study: an investigative randomized control study using purified isoflavones in men with rising prostatespecific antigen," Cancer Science, vol. 103, no. 1, pp. 125130, 2012.

[77] G. Q. Zhang, J. L. Chen, Q. Liu, Y. Zhang, H. Zeng, and Y. Zhao, "Soy intake is associated with lower endometrial cancer risk: a systematic review and meta-analysis of observational studies," Medicine (Baltimore), vol. 94, no. 50, article e2281, 2015.

[78] X. S. Zhong, J. Ge, S. W. Chen, Y. Q. Xiong, S. J. Ma, and Q. Chen, "Association between dietary isoflavones in soy and legumes and endometrial cancer: a systematic review and meta-analysis," Journal of the Academy of Nutrition and Dietetics, vol. 118, no. 4, pp. 637-651, 2018.

[79] A. Cassidy, T. Huang, M. S. Rice, E. B. Rimm, and S. S. Tworoger, "Intake of dietary flavonoids and risk of epithelial ovarian cancer," The American Journal of Clinical Nutrition, vol. 100, no. 5, pp. 1344-1351, 2014.

[80] X. Hua, L. Yu, R. You et al., "Association among dietary flavonoids, flavonoid subclasses and ovarian cancer risk: a meta-analysis," PLoS One, vol. 11, no. 3, pp. e0151134e0151134, 2016.

[81] F. Chi, R. Wu, Y. C. Zeng, R. Xing, Y. Liu, and Z. G. Xu, "Post-diagnosis soy food intake and breast cancer survival: a meta-analysis of cohort studies," Asian Pacific Journal of Cancer Prevention, vol. 14, no. 4, pp. 2407-2412, 2013.

[82] H. Akaza, "Prostate cancer chemoprevention by soy isoflavones: role of intestinal bacteria as the "second human genome"," Cancer Science, vol. 103, no. 6, pp. 969-975, 2012.

[83] M. D. van Die, K. M. Bone, S. G. Williams, and M. V. Pirotta, "Soy and soy isoflavones in prostate cancer: a systematic review and meta-analysis of randomized controlled trials," BJU international, vol. 113, pp. E119-E130, 2014.

[84] Q. Zhang, H. Feng, B. Qluwakemi et al., "Phytoestrogens and risk of prostate cancer: an updated meta-analysis of epidemiologic studies," International Journal of Food Sciences and Nutrition, vol. 68, no. 1, pp. 28-42, 2017.

[85] L. Yan, E. L. Spitznagel, and M. C. Bosland, "Soy consumption and colorectal cancer risk in humans: a meta-analysis," Cancer Epidemiology and Prevention Biomarkers, vol. 19, no. 1, pp. 148-158, 2010.

[86] H. D. Woo and J. Kim, "Dietary flavonoid intake and risk of stomach and colorectal cancer," World journal of gastroenterology: WJG, vol. 19, no. 7, pp. 1011-1019, 2013.

[87] X. Zhang, X. O. Shu, Y. T. Gao et al., "Soy food consumption is associated with lower risk of coronary heart disease in Chinese women," The Journal of nutrition, vol. 133, no. 9, pp. 2874-2878, 2003.

[88] Y. Kokubo, H. Iso, J. Ishihara, K. Okada, M. Inoue, and S. Tsugane, "Association of dietary intake of soy, beans, and isoflavones with risk of cerebral and myocardial infarctions in Japanese populations: the Japan Public Health Centerbased (JPHC) study cohort I," Circulation, vol. 116, no. 22, pp. 2553-2562, 2007.

[89] M. Talaei, W. P. Koh, R. M. van Dam, J. M. Yuan, and A. Pan, "Dietary soy intake is not associated with risk of cardiovascular disease mortality in Singapore Chinese adults," The Journal of nutrition, vol. 144, no. 6, pp. 921-928, 2014.

[90] Y. T. van der Schouw, S. Kreijkamp-Kaspers, P. H. Peeters, L. Keinan-Boker, E. B. Rimm, and D. E. Grobbee, "Prospective study on usual dietary phytoestrogen intake and cardiovascular disease risk in Western women," Circulation, vol. 111, no. 4, pp. 465-471, 2005.

[91] X. Zhang, Y. T. Gao, G. Yang et al., "Urinary isoflavonoids and risk of coronary heart disease," International journal of epidemiology, vol. 41, no. 5, pp. 1367-1375, 2012.

[92] N. González Cañete and A. S. Durán, "Soya isoflavones and evidences on cardiovascular protection," Nutrición Hospitalaria, vol. 29, no. 6, pp. 1271-1282, 2014.

[93] J. W. Anderson, B. M. Johnstone, and M. E. Cook-Newell, "Meta-analysis of the effects of soy protein intake on serum lipids," New England Journal of Medicine, vol. 333, no. 5, pp. 276-282, 1995.

[94] M. Glisic, N. Kastrati, J. Musa et al., "Phytoestrogen supplementation and body composition in postmenopausal women: a systematic review and meta-analysis of randomized controlled trials," Maturitas, vol. 115, pp. 74-83, 2018.

[95] R. L. Thomson, G. D. Brinkworth, M. Noakes, and J. D. Buckley, "Muscle strength gains during resistance exercise training are attenuated with soy compared with dairy or usual protein intake in older adults: a randomized controlled trial," Clinical Nutrition, vol. 35, no. 1, pp. 27-33, 2016.

[96] F. L. Orsatti, N. Maestá, E. P. de Oliveira et al., “Adding soy protein to milk enhances the effect of resistance training on muscle strength in postmenopausal women," Journal of Dietary Supplements, vol. 15, no. 2, pp. 140-152, 2018.

[97] M. L. Casini, G. Marelli, E. Papaleo, A. Ferrari, F. D'Ambrosio, and V. Unfer, "Psychological assessment of the effects of treatment with phytoestrogens on postmenopausal women: a randomized, double-blind, crossover, placebo- controlled study," Fertility and Sterility, vol. 85, no. 4, pp. 972-978, 2006.

[98] R. F. Santos-Galduróz, J. C. Galduróz, R. L. Facco, H. Hachul, and S. Tufik, "Effects of isoflavone on the learning and memory of women in menopause: a double-blind placebocontrolled study," Brazilian Journal of Medical and Biological Research, vol. 43, no. 11, pp. 1123-1126, 2010.

[99] G. A. Greendale, M. H. Huang, K. Leung et al., "Dietary phytoestrogen intakes and cognitive function during the menopausal transition: results from the Study of Women's Health Across the Nation Phytoestrogen Study," Menopause, vol. 19, no. 8, pp. 894-903, 2012.

[100] V. W. Henderson, J. A. St John, H. N. Hodis et al., "Longterm soy isoflavone supplementation and cognition in women: a randomized, controlled trial," Neurology, vol. 78, no. 23, pp. 1841-1848, 2012.

[101] C. E. Gleason, B. L. Fischer, N. M. Dowling et al., "Cognitive effects of soy isoflavones in patients with Alzheimer's disease," Journal of Alzheimer's Disease, vol. 47, no. 4, pp. 1009-1019, 2015.

[102] L. S. Schneider, G. Hernandez, L. Zhao et al., "Safety and feasibility of estrogen receptor- $\beta$ targeted phytoSERM 
formulation for menopausal symptoms: phase $1 \mathrm{~b} / 2 \mathrm{a}$ randomized clinical trial," Menopause, vol. 26, no. 8, pp. 874884, 2019.

[103] F. M. Steinberg, M. J. Murray, R. D. Lewis et al., "Clinical outcomes of a $2-y$ soy isoflavone supplementation in menopausal women," The American Journal of Clinical Nutrition, vol. 93, no. 2, pp. 356-367, 2011.

[104] L. Sosvorová, P. Mikšátková, M. Bičíková, N. Kaňová, and O. Lapčík, "The presence of monoiodinated derivates of daidzein and genistein in human urine and its effect on thyroid gland function," Food and chemical toxicology, vol. 50, no. 8, pp. 2774-2779, 2012.

[105] H. L. Dong, X. Y. Tang, Y. Y. Deng et al., "Urinary equol, but not daidzein and genistein, was inversely associated with the risk of type 2 diabetes in Chinese adults," European Journal of Nutrition, vol. 59, no. 2, pp. 719-728, 2020.

[106] C. P. Gobert, E. A. Pipe, S. E. Capes, G. A. Darlington, J. W. Lampe, and A. M. Duncan, "Soya protein does not affect glycaemic control in adults with type 2 diabetes," British Journal of Nutrition, vol. 103, no. 3, pp. 412-421, 2010.

[107] Y. B. Ye, A. L. Chen, W. Lu et al., "Daidzein and genistein fail to improve glycemic control and insulin sensitivity in Chinese women with impaired glucose regulation: a doubleblind, randomized, placebo-controlled trial," Molecular Nutrition \& Food Research, vol. 59, no. 2, pp. 240-249, 2015.

[108] T. Usui, M. Tochiya, Y. Sasaki et al., "Effects of natural Sequol supplements on overweight or obesity and metabolic syndrome in the Japanese, based on sex and equol status," Clinical endocrinology, vol. 78, no. 3, pp. 365-372, 2013.

[109] R. Zamora-Ros, V. Knaze, L. Luján-Barroso et al., "Dietary intakes and food sources of phytoestrogens in the European prospective investigation into cancer and nutrition (EPIC) 24-hour dietary recall cohort," European Journal of Clinical Nutrition, vol. 66, no. 8, pp. 932-941, 2012.

[110] K. K. L. Chan, M. K. Y. Siu, Y. X. Jiang, J. J. Wang, T. H. Y. Leung, and H. Y. S. Ngan, "Estrogen receptor modulators genistein, daidzein and ERB-041 inhibit cell migration, invasion, proliferation and sphere formation via modulation of FAK and PI3K/AKT signaling in ovarian cancer," Cancer Cell International, vol. 18, no. 1, 2018.

[111] I. Rietjens, J. Louisse, and K. Beekmann, "The potential health effects of dietary phytoestrogens," British journal of pharmacology, vol. 174, no. 11, pp. 1263-1280, 2017.

[112] J. Lampe and M. Messina, "Are Phytoestrogens Nature's Cure for What Ails Us? A Look at the Research," Journal of the American Dietetic Association, vol. 98, no. 9, pp. 974-976, 1998.

[113] A. Devine, I. M. Dick, S. S. Dhaliwal, R. Naheed, J. Beilby, and R. L. Prince, "Prediction of incident osteoporotic fractures in elderly women using the free estradiol index," Osteoporosis International, vol. 16, no. 2, pp. 216-221, 2005.

[114] D. Shor, T. Sathyapalan, S. L. Atkin, and N. J. Thatcher, "Does equol production determine soy endocrine effects?," European Journal of Nutrition, vol. 51, no. 4, pp. 389-398, 2012.

[115] C. Nagata, T. Mizoue, K. Tanaka et al., "Soy intake and breast cancer risk: an evaluation based on a systematic review of epidemiologic evidence among the Japanese population," Japanese journal of clinical oncology, vol. 44, no. 3, pp. 282-295, 2014.

[116] S. M. Mense, F. Remotti, A. Bhan et al., "Estrogen-induced breast cancer: alterations in breast morphology and oxidative stress as a function of estrogen exposure," Toxicology and applied pharmacology, vol. 232, no. 1, pp. 78-85, 2008.

[117] J. M. Guo, G. Z. Kang, B. X. Xiao, D. H. Liu, and S. Zhang, "Effect of daidzein on cell growth, cell cycle, and telomerase activity of human cervical cancer in vitro," International Journal of Gynecologic Cancer, vol. 14, no. 5, pp. 882-888, 2004.

[118] Y. He, X. Wu, Y. Cao et al., "Daidzein exerts anti-tumor activity against bladder cancer cells via inhibition of FGFR3 pathway," Neoplasma, vol. 63, no. 4, pp. 523-531, 2016.

[119] O. Kucuk, "Soy foods, isoflavones, and breast cancer," Cancer, vol. 123, no. 11, pp. 1901-1903, 2017.

[120] Y. Li, S. Li, X. Meng, R. Y. Gan, J. J. Zhang, and H. B. Li, "Dietary natural products for prevention and treatment of breast cancer," Nutrients, vol. 8, p. 9, 2017.

[121] A. Vardi, R. Bosviel, N. Rabiau et al., "Soy phytoestrogens modify DNA methylation of GSTP1, RASSF1A, EPH2 and BRCA1 promoter in prostate cancer cells," In vivo, vol. 24, no. 4, pp. 393-400, 2010.

[122] F. Hua, C. H. Li, X. G. Chen, and X. P. Liu, "Daidzein exerts anticancer activity towards SKOV3 human ovarian cancer cells by inducing apoptosis and cell cycle arrest, and inhibiting the Raf/MEK/ERK cascade," International journal of molecular medicine, vol. 41, no. 6, pp. 3485-3492, 2018.

[123] G. L. Russo and P. Ungaro, "Epigenetic mechanisms of quercetin and other flavonoids in cancer therapy and prevention," in Epigenetics of Cancer Prevention, pp. 187-202, Academic Press, 2019.

[124] S. Mishra, S. S. Verma, V. Rai et al., "Long non-coding RNAs are emerging targets of phytochemicals for cancer and other chronic diseases," Cellular and Molecular Life Sciences, vol. 76, no. 10, pp. 1947-1966, 2019.

[125] G. Maskarinec, E. Erber, M. Verheus et al., "Soy consumption and histopathologic markers in breast tissue using tissue microarrays," Nutrition and Cancer, vol. 61, no. 5, pp. 708716, 2009.

[126] M. Adjakly, M. Ngollo, A. Lebert et al., "Comparative effects of soy phytoestrogens and $17 \beta$-estradiol on DNA methylation of a panel of 24 genes in prostate cancer cell lines," Nutrition and Cancer, vol. 66, no. 3, pp. 474-482, 2014.

[127] A. M. Mahmoud, W. Yang, and M. C. Bosland, "Soy isoflavones and prostate cancer: a review of molecular mechanisms," The Journal of steroid biochemistry and molecular biology, vol. 140, pp. 116-132, 2014.

[128] M. Messina and G. Redmond, "Effects of soy protein and soybean isoflavones on thyroid function in healthy adults and hypothyroid patients: a review of the relevant literature," Thyroid, vol. 16, no. 3, pp. 249-258, 2006.

[129] M. Principi, A. di Leo, M. Pricci et al., "Phytoestrogens/insoluble fibers and colonic estrogen receptor $\beta$ : randomized, double-blind, placebo-controlled study," World Journal of Gastroenterology: WJG, vol. 19, no. 27, pp. 4325-4333, 2013.

[130] N. Gottstein, B. A. Ewins, C. Eccleston et al., "Effect of genistein and daidzein on platelet aggregation and monocyte and endothelial function," British Journal of Nutrition, vol. 89, no. 5, pp. 607-615, 2003.

[131] M. Hamalainen, R. Nieminen, P. Vuorela, M. Heinonen, and E. Moilanen, "Anti-inflammatory effects of flavonoids: genistein, kaempferol, quercetin, and daidzein inhibit STAT-1 and NF-kappaB activations, whereas flavone, isorhamnetin, naringenin, and pelargonidin inhibit only NF-kappaB activation 
along with their inhibitory effect on iNOS expression and NO production in activated macrophages," Mediators of Inflammation, vol. 2007, Article ID 45673, 10 pages, 2007.

[132] D. D. Zhou, M. Luo, A. Shang et al., "Antioxidant food components for the prevention and treatment of cardiovascular diseases: effects, mechanisms, and clinical studies," Oxidative Medicine and Cellular Longevity, vol. 2021, Article ID 6627355, 17 pages, 2021.

[133] L. M. Miller, J. W. Lampe, K. M. Newton et al., "Being overweight or obese is associated with harboring a gut microbial community not capable of metabolizing the soy isoflavone daidzein to _O-_ desmethylangolensin in peri- and postmenopausal women," Maturitas, vol. 99, pp. 37-42, 2017.

[134] V. W. Henderson, A. Paganini-Hill, B. L. Miller et al., "Estrogen for Alzheimer's disease in women: randomized, doubleblind, placebo-controlled trial," Neurology, vol. 54, no. 2, pp. 295-301, 2000.

[135] J. Wei, F. Yang, C. Gong, X. Shi, and G. Wang, "Protective effect of daidzein against streptozotocin-induced Alzheimer's disease via improving cognitive dysfunction and oxidative stress in rat model," Journal of biochemical and molecular toxicology, vol. 33, article e22319, 2019.

[136] G. Hernandez, L. Zhao, A. A. Franke et al., "Pharmacokinetics and safety profile of single-dose administration of an estrogen receptor $\beta$-selective phytoestrogenic (phytoSERM) formulation in perimenopausal and postmenopausal women," Menopause, vol. 25, no. 2, pp. 191-196, 2018.

[137] J. A. Eden, "Phytoestrogens for menopausal symptoms: a review," Maturitas, vol. 72, no. 2, pp. 157-159, 2012.

[138] B. Y. Li, X. Y. Xu, R. Y. Gan et al., "Targeting gut microbiota for the prevention and management of diabetes mellitus by dietary natural products," Foods, vol. 25, p. 8, 2019.

[139] R. K. Al-Ishaq, M. Abotaleb, P. Kubatka, K. Kajo, and D. Busselberg, "Flavonoids and their anti-diabetic effects: cellular mechanisms and effects to improve blood sugar levels," Biomolecules, vol. 9, no. 9, p. 430, 2019.

[140] J. Y. Fang, C. H. Lin, T. H. Huang, and S. Y. Chuang, "In vivo rodent models of type 2 diabetes and their usefulness for evaluating flavonoid bioactivity.," Nutrients, vol. 11, no. 3, p. 530, 2019.

[141] S. H. Cheong, K. Furuhashi, K. Ito et al., "Daidzein promotes glucose uptake through glucose transporter 4 translocation to plasma membrane in L6 myocytes and improves glucose homeostasis in type 2 diabetic model mice," The Journal of Nutritional Biochemistry, vol. 25, no. 2, pp. 136-143, 2014.

[142] M. T. Velasquez and S. J. Bhathena, "Role of dietary soy protein in obesity," International journal of medical sciences, vol. 4, no. 2, pp. 72-82, 2007.

[143] C. Zimmermann, C. R. Cederroth, L. Bourgoin, M. Foti, and $\mathrm{S}$. Nef, "Prevention of diabetes in $\mathrm{db} / \mathrm{db}$ mice by dietary soy is independent of isoflavone levels," Endocrinology, vol. 153, no. 11, pp. 5200-5211, 2012.

[144] A. Ørgaard and L. Jensen, "The effects of soy isoflavones on obesity," Experimental Biology and Medicine, vol. 233, no. 9, pp. 1066-1080, 2008.

[145] J. Most, G. H. Goossens, J. W. Jocken, and E. E. Blaak, "Shortterm supplementation with a specific combination of dietary polyphenols increases energy expenditure and alters substrate metabolism in overweight subjects," International Journal of Obesity, vol. 38, no. 5, pp. 698-706, 2014.
[146] C. S. Rosenfeld, "Effects of phytoestrogens on the developing brain, gut microbiota, and risk for neurobehavioral disorders," Frontiers in nutrition, vol. 6, p. 142, 2019.

[147] Y. Vandenplas, P. G. Castrellon, R. Rivas et al., "Safety of soya-based infant formulas in children," British journal of nutrition, vol. 111, no. 8, pp. 1340-1360, 2014.

[148] H. Anandhi Senthilkumar, J. E. Fata, and E. J. Kennelly, "Phytoestrogens: the current state of research emphasizing breast pathophysiology," Phytotherapy Research, vol. 32, no. 9, pp. 1707-1719, 2018. 